\title{
Study of Microbial Community of Hydrocarbon Impacted Sites of Bodo Oilfield, Ogoniland Rivers State, Nigeria
}

\author{
Gbode, Lekia Yenor and Wiri, Thankgod Bariyaa \\ Department of Environmental Health Technology, \\ Rivers state college of health science and Management Technology, \\ Port Harcourt, Nigeria.
}

\begin{abstract}
Hydrocarbon pollution has greatly altered the normal microbial flora of our environments; this has led to the succession of hydrocarbonoclastic microbes in oil impacted sites. This study is a comparative study of the microbial flora of hydrocarbon impacted site of Bodo oilfield and the non-impacted site in Ogoniland. A total of 12 samples were collected, 6 from the oil impacted site, and 6 from the non-impacted site. The sample were coded A-F. The physicochemical parameter of soil was determined, the microbiological examination was conducted to determine the bacterial and fungal communities present at each site. The result shows that higher population of oil-degrading microorganisms were found on the hydrocarbon impacted site, prominent among them were Micrococcus, Acinetobacter, Corynebacterium, Bacillus, Pseudomonas, Flavobacterium, Actinomycetes, fungi isolated from impacted sites includes Candida, Rhizopus mucor and Aspergillus, while the non-impacted site has: streptococcus, staphylococcus, E.coli, and Actinomycetes species. There were also fungal isolate of which only Candida was the only isolate. A microbial growth ranges between $1.1 \times 103$ to $9.1 \times 103 \mathrm{CFU} / \mathrm{ml}$.
\end{abstract}

Key words: Microbial, Community, Hydrocarbon, Impacted sites.

\section{INTRODUCTION}

Many oil-producing communities have been suffering from the after effects of oil spillage. The accidental discharge of petroleum products on soil or water surfaces is termed oil spill. Oil-spill pollution has been hazardous and problematic World-wide (Vincent, 1980) Crude oil is a heterogeneous liquid consisting of hydrocarbons. Most oil spill occur as a result microorganism which causes the deterioration of the product leading to corrosion of pipelines and storage tanks (wiri and Igoma 2020) Crude oil is classified according to its distillation residues as paraffin, naphtha or aromatics and based on the relative proportions of the heavy molecular weight constituents are classified as light, medium or heavy oils. This, however, results in the accidental discharge of petroleum product into the environment, causing severe and lasting damages which often alters the microbial flora of that impacted environment.

\section{MATERIALS AND METHODS}

Soil samples used for this study were collected using opaque polyethen bags. Samples were collected from hydrocarbon impacted sites of Bodo community in Gokana Local government area of Rivers State. A Total of six soil sample were collected each, from the oil impacted and none oil impacted site around Bodo oilfield. The samples were labelled A-F and were immediately transported to the laboratory for analysis. Microbiological examinations were conducted to ascertain the various microbial flora of each site (oil impacted and none oil impacted) In the laboratory, $10 \mathrm{~g}$ of each of the soil samples was weighed and transferred into $250 \mathrm{ml}$ flask containing $90 \mathrm{ml}$ of sterile distilled water. The suspensions were shaken intermittently for about $30 \mathrm{~mm}$. Each solution was allowed to stand for about $1 \mathrm{~h}$ after which the suspension was decanted into another $250 \mathrm{ml}$ flask. Serial dilution of each suspension was made up dilution 6. The physicochemical parameter of the various soil were also determine. SDA was used in fungi cultivation while nutrient agar was use to cultivate bacteria 
International Journal of Research in Agriculture, Biology \& Environment (ijagri), Volume 1, Issue 2, 2020

Table 1: Total microbial Community of soil samples from Bodo oil Field

\begin{tabular}{|l|l|l|l|l|}
\hline Sample & \multicolumn{2}{|l|}{ Oil-impacted site } & \multicolumn{2}{l|}{ Non oil-impacted site } \\
\hline & Bacteria (CFU/g) & Fungi (CFU/g) & Bacteria (CFU/g) & Fungi (CFU/g) \\
\hline A & $8.4 \times 10^{3}$ & $10 \times 10^{4}$ & $1.8 \times 10^{3}$ & $2.0 \times 10^{4}$ \\
\hline B & $5.8 \times 10^{3}$ & $7.3 \times 10^{4}$ & $1.6 \times 10^{3}$ & $8.0 \times 10^{4}$ \\
\hline C & $7.5 \times 10^{3}$ & $4.4 \times 10^{4}$ & $1.1 \times 10^{3}$ & $7 \times 10^{4}$ \\
\hline D & $9.4 \times 10^{3}$ & $3.3 \times 10^{4}$ & $1.2 \times 10^{3}$ & $8 \times 10^{4}$ \\
\hline E & $7.1 \times 10^{3}$ & $5.7 \times 10^{4}$ & $2.2 \times 10^{3}$ & $5 \times 10^{4}$ \\
\hline F & $91 \times 10^{3}$ & $21 \times 10^{4}$ & $21 \times 10^{3}$ & $71 \times 10^{4}$ \\
\hline
\end{tabular}

Table 2. Identified bacteria isolates from the oil impacted site of Bodo

\begin{tabular}{|l|l|}
\hline Oil-impacted site & Non-oil impacted site \\
\hline Pseudomonas species & Pseudomonas species \\
\hline Bacillus species & Staphylococcus species \\
\hline Micrococcus species & Bacilus species \\
\hline Acinetobacter species & Actinomycetes spp \\
\hline Corynebacterium species & E.coli \\
\hline Flavobacterium species & Actinomycetes \\
\hline Actinomycetes species & Streptococcus species \\
\hline
\end{tabular}

Table 3. Identified Fungi isolates from the oil impacted site of Bodo oil fied

\begin{tabular}{|l|l|l|l|}
\hline Sample & Morphology & Type of organism & Species \\
\hline oil-impacte site & Ovoid spheres & yeast-like & Candida spp \\
\hline & Filamentous & Mold & Arthrobacter spp \\
\hline & Filamentous & Mold & Rhizopus spp \\
\hline & Filamentous & Mold & Aspergillus spp \\
\hline Non oil-impacted site & Ovoid Spheres & Yeast-like mold & candida spp \\
\hline
\end{tabular}


International Journal of Research in Agriculture, Biology \& Environment (ijagri), Volume 1, Issue 2, 2020

Table 4, physicochemical parameter of soil

\begin{tabular}{|l|l|l|l|}
\hline & Parameter & Impacted soil & $\begin{array}{l}\text { Non impacted } \\
\text { soil }\end{array}$ \\
\hline & PH & 7.50 & 7.20 \\
\hline & iron $(\mathrm{mg} / \mathrm{kg})$ & 18.50 & 7.50 \\
\hline & EC & 1437 & 1012 \\
\hline & Cadmium $(\mathrm{mg} / \mathrm{kg})$ & $<0.001$ & $<0.001$ \\
\hline & Oil and grease $(\mathrm{mg} / \mathrm{kg})$ & 32070 & 400 \\
\hline & Lead $(\mathrm{mg} / \mathrm{kg})$ & 0.002 & 0.000 \\
\hline & Zinc $(\mathrm{mg} / \mathrm{kg})$ & 0.089 & 0.016 \\
\hline & Arsenic $(\mathrm{mg} / \mathrm{kg})$ & $<0.001$ & $<0.001$ \\
\hline & Chromium $(\mathrm{mg} / \mathrm{kg})$ & $<0.001$ & $<0.001$ \\
\hline
\end{tabular}

\section{RESULTS AND DISCUSSION}

Result shows the microbial counts (Table1) of oil impacted and none impacted soil in Bodo oil field. Areas that are impacted have high microbial counts. Microbial counts from the none impacted sites were low , This result agrees with works of Wiri, Desmond, Mbato, and Nabiradee (2019) which reported that a higher microbial counts is usually associate with oil polluted sites . Table 2 is the results of the various microbial isolates, prominent among isolates from the impacted sites are Micrococcus, Acinetobacter ,Corynebacteriu, Bcilus, Pseudomonas, Flavobacterium, Actinomycetes species while isolates from non-impacted sites includes Staphylococcus, Bacilus, Streptococcus species. Table 3 shows morphological features and fungi isolates from oil impacted and non-oil impacted sites, Candida was predominantly fungal species from oil-impacted site, others includes Mucor, Rhizopus, Arthrobacter and Aspergillus while predominantly Candida was the only fungal isolate from non-impacted site of Bodo oilfield. Table 4 show results of the various physical and chemical attributes of the soil sample of both oil impacted and non-impacted soil. The slight difference in bacterial population of the two areas might be due to the effect of slight increase in the acidity of the soil spilled with crude oil. Following every oil spillage, there is always slight increase in soil acidity of the affected environment mostly when the spilled petroleum compounds are of high sulphur content (Hans, 1962). This explains the slight decrease in bacterial population in the oil-spilled area. The fungal population may have increased due to the fact that fungi tolerate acidic environment than bacteria. Also the depletion in the oxygen level of the spilled area contributed to the population differences. There were no growing grasses around the area spilled with crude oil as at the time of the study which differs from non-polluted sites where there were much green grasses growing, This result agrees with the results of Okereke, Obiekezie and Obasi (2007)

\section{CONCLUSION}

It is concluded that hydrocarbon pollution enhances the proliferation of hydrocarbon degrading microorganism of which Pseudomonas and Candida are prominent among them. The Significance of the result is that it will be a reference point to somilar research within Nigeria . The petroleum industry will find result obtained from this study of immense significance.

\section{REFERENCES}

Hans, J.O (1962). Microbiological studies of oil and gas pipelines. Technology bulletin. pp 135.

John G Holt (1993). Bergy’s Manual of Determinative Bacteriology (8th edition). Lippin cottW.Willams, USA. p.816.

Okereke, J. N, Obiekezie, S.O, and Obasi, K.O. (2007)Microbial flora of oil spilled sites in Egbema, Imo state Nigeria. African Journal of biotechnology. Vol 6(8) pp 991-993

Wiri, T.B, Desmon O. Mbato, C,I, Nabiradee, PN. (2019) Bioremediation potentials of hydrocarbonosclastic bacteria indigenous in the oil impacted sites of ogoniland, Rivers state Nigeria. International journal of research and innovation in applied science vol. 4(8) pp 107-109

Wiri, Thankgod Bariyaa and Igoma, Promise Sunday (2020) The Effects of Biodeterioration due to microbial growth in diesel, control using optimization of sulphur and consequencies on Nigerian economy. International journal of chemical science. Vol 4 (1) 